\title{
EL ESPECTÁCULO, LA CÁMARA, LA AUTORÍA Y LA VIGILANCIA EN EL FOUND FOOTAGE*
}

\author{
Sergio José Aguilar Alcalá** \\ Universidad Iberoamericana \\ sergio.aguilaralcala@gmail.com
}

Recibido: 14/5/2020 Aceptado: 15/7/2020

DOI: https://doi.org/10.26439/contratexto2020.n034.4864

Resumen. Se discuten las características de las películas conocidas como found footage a través de la ontología de la cámara, la distinción entre ficción y no ficción, la distinción entre filmación y película, y entre un autor explícito y una agencia autoral de la enunciación. Para ello serán esenciales los aportes de Edward Branigan y Carl Plantinga. Se analizan películas a partir de estos ejes, donde se trata de entender el modo singular en que cada filme articula el problema universal del género: la brecha entre el enunciado y la enunciación. Esta grieta irreductible, del modo en que la plantea el psicoanálisis, es necesaria para comprender el tipo de verdad que puede encontrarse en el found footage.

Palabras clave: found footage / metraje encontrado / cámara de cine / ficción y no ficción / enunciado y enunciación

\section{SPECTACLE, CAMERA, AUTHORSHIP AND SURVEILLANCE IN 'FOUND FOOTAGE'}

Abstract. This paper discusses the characteristics of films known as 'found footage' through the ontology of the cinematic camera, and the distinction between fiction and nonfiction, between the shooting of a film and the film itself, and between an explicit author and the enunciation authorship. To that end, the theories of Edward Branigan and Carl Plantinga will be essential. The films are analyzed based on these theories, aiming to understand the singular way in which each film articulates the universal

\footnotetext{
* "Extimacies: Critical Theory from the Global South", proyecto financiado por la Andrew Mellon Grant postMA fellowship.

** Maestro en Comunicación por la Universidad Nacional Autónoma de México (véase https://orcid.org/00000002-1712-753X).
} 
issue of the genre: the gap between the enunciated content and its enunciation. This irreductible gap, as psychoanalysis understands it, is necessary to understand the kind of truth that may be found in 'found footage'.

Keywords: found footage / cinematic camera / fiction and nonfiction / enunciated content and enunciation

\section{O SPETÁCULO, A CÂMERA, A AUTORIA E A VIGILÂNCIA NAS FOUND FOOTAGE}

Resumo. As características dos filmes conhecidos como found footage são discutidas através da ontologia da câmera, a distinção entre ficção e não ficção, a distinção entre filmagem e filme, e entre um autor explícito e uma agência autoral da enunciação. Para isso, as contribuições de Edward Branigan e Carl Plantinga serão essenciais. Analisa-se aqui os filmes a partir desses eixos, onde se pretende entender a maneira singular na qual cada filme articula o problema universal do gênero: a brecha entre o enunciado e a enunciação.. Essa abertura irredutível, como a psicanálise aponta, é necessária para entender o tipo de verdade que pode ser encontrada nas found footage.

Palabras-chave: found footage / metragem encontrada / câmera de cinema / ficção e não-ficção / enunciadoe enunciação 
"Pasa en las películas, pasa en la vida, pasa en TNT". Ese fue el eslogan de una campaña para Latinoamérica del canal de televisión TNT, dedicado a transmitir películas. Diversos personajes se enfrentaban a situaciones ridículas (una mujer cantando en la ducha, un hombre tratando de llevar bebidas a través de un antro) que terminaban recordando a icónicas escenas del cine.

Este eslogan establece una distinción entre las películas y la vida, pues la conexión referida entre ellas es contingente, en los objetos o diálogos. ¿Podríamos imaginar un espacio donde las películas sean la vida misma, o donde la vida sea una película, no al nivel de los objetos y diálogos, sino al nivel de su representación? Quizá es lo que podemos plantear con un fenómeno que se popularizó a finales de los noventa y durante la primera década del siglo xxı, que predijo el momento de hiperconexión a múltiples pantallas que vivimos hoy. Se trata del cine de metraje encontrado o, por su nombre en inglés como me referiré a él en el resto de este texto, el found footage.

De acuerdo con su nombre, el found footage es un tipo de películas que se distingue no por su tema, sino por la relación específica que tiene la edición en ellos: por alguna circunstancia, no hubo un proceso de finalización en la realización del filme, así que se presenta lo que fue encontrado. A falta de un proceso de edición, como se argumentará, es el propio dispositivo de la cámara cinematográfica el que parece adquirir una agencia autoral.

La cámara cinematográfica no es solo un instrumento de registro, sino también una agencia que registra (esta aclaración será la primera parte de este artículo). Con esta distinción, se puede diferenciar entre ficción y no ficción desde la relación de la cámara con la diégesis, y así se señala al found footage como un fenómeno donde la función objetual de la cámara en el espacio diegético se espectaculariza: lo espectacular no es la película, sino la grabación de la película.

Tras esta discusión teórica que desemboca en ejes clave de análisis, este artículo pasará a la revisión de varias películas found footage de diverso origen. Notaremos, entonces, una brecha entre lo que se registra por la cámara y el lugar desde el que se registra (la agencia que enuncia). Esta brecha irreductible es, como ha señalado el psicoanálisis, el precio que se paga por habitar el lenguaje: la irreductible incorrespondencia entre lo que se dice y el decir. El found footage es una película que espectaculariza el decir.

1 Aceptando que la distinción puede resultar esencial en una discusión tecnológica o sobre técnicas de producción cinematográfica, en este artículo usaré grabar y filmar de manera indistinta, pues averiguar si se hace en una cinta magnética, una tarjeta SD o en super-8 no es una dimensión que competa al análisis y discusión que aquí pretendo llevar. 


\section{LA CÁMARA Y LA ENUNCIACIÓN}

Habrá que señalar las consecuencias de algo que tomamos como evidente: la cámara de cine es un objeto que sirve para registrar algo. Incluso en esas primeras y primitivas películas de finales del siglo XIX, la cámara no estaba "aleatoriamente" grabando, sino que estaba grabando algo, ya sea hombres y mujeres saliendo de una fábrica o un tren que se aproxima.

Esto supone, como señala Rojas (2015, p. 288), que el cine no "captura" imágenes, ni el de ficción ni el de no ficción, pues las imágenes no existen por sí mismas como entes que puedan ser "atrapados", que estén ahí esperando a ser registrados.

Es en el registro de la cámara, en lo que se grabó, donde puede discernirse la existencia de una intención de registro. No es clara la intención específica (por qué lo hicieron, qué esperaban conseguir), pero sí el hecho de que hubo una intención ${ }^{2}$. La cámara de cine funciona, primigeniamente, como el enlace entre un hecho y la intención de registrar ese hecho: una filmación no solo señala un hecho (un hecho que está filmado), sino también la intención de filmar ese hecho. Es decir, si entendemos el registro de la cámara como un documento, asumimos que todo documento es su propia documentación: a la vez que es documento de algo, carga la huella de su propio documentar. Esto es, precisamente, el enunciado y la enunciación.

Nótese que la cámara de cine actúa no solo como un instrumento para registrar un hecho, sino también, como indica Edward Branigan, para señalar un punto de vista (el del que filma ${ }^{3}$ ). Este punto de vista, lejos de simplemente ser el "autor" de lo registrado, es un marco fundamental para comprender la relación de la cámara con lo filmado:

¿El punto de vista de quién debe ser analizado como encarnado en una cámara?, ¿el autor, el autor implícito, el narrador tácito, el narrador explícito, el observador invisible, el personaje, el espectador ideal o el espectador real, por nombrar algunas posibilidades? Con la cuestión de la subjetividad, la naturaleza del movimiento de cámara cambia de investigar "movimiento", "motivo", "motivación" y "fuerza motiva" a nociones explícitas de agencia, intención, propósito, y el uso de una retórica adecuada designada para movilizar al espectador. (Branigan, 2006, p. 40) ${ }^{4}$

2 Aquí estoy obviando, por supuesto, momentos en los que sin intención se quedó grabando una cámara, en donde de todos modos hallamos una intención en su inclusión en el producto final mediante la edición. Un lugar diferente ocupa el registro de las cámaras de vigilancia, como en un caso analizado más adelante.

3 Debo señalar que "el que filma" es el sujeto de la enunciación, no una persona específica. Esto es lo que alejaría a la operatividad del enunciado/enunciación de cualquier "teoría del autor", o cualquier psicologización del autor: no se trata de una persona, sino de un rol estructural. Para comenzar esta distinción, sugiero partir de Arnheim (1958).

4 "Whose point of view needs to be analyzed as being embodied in a camera: the author, implied author, tacit narrator, explicit narrator, invisible observer, character, ideal spectator, or actual spectator, to name a few possibilities? With the question of subjectivity, the nature of camera movement 
Así, la cámara de cine se convierte en un agente que señala una brecha entre los objetos y su registro, introduciendo la dimensión de un sujeto que enuncia ${ }^{5}$. Este sujeto que enuncia, a su vez, nos permite abstraernos de esta primera distinción (objetos vs. registro de objetos) y entrar en una segunda distinción más interesante: la representación y la representación de la experiencia del sujeto que enuncia. Esta discusión es el campo de la subjetividad cinematográfica.

Entendamos por hecho cinematográfico al material fílmico que reconocemos como tal, y se diferencia en su cualidad de registro fílmico de cualquier cosa que aparezca registrada 6 . Cuando registro en mi celular la muerte de una persona, se abren dos hechos: la muerte misma y el registro de la muerte en video (el segundo es el hecho cinematográfico, es con lo que se lidia al analizar cine). Lo que se apunta, por tanto, es que si el cine supone siempre un registro intencional de algo, entonces, el objeto o hecho "real" a partir del cual se hace el registro no solo no es parte del hecho cinematográfico, sino que supone un obstáculo epistemológico para entender al propio hecho cinematográfico.

Como no tenemos acceso al hecho, entonces habrá que ver más bien la brecha entre el registro y el sujeto que registró. Cuando el cine nos muestra cosas borrosas/ deficientes/ocultas/"sin sentido", debemos asumir que las cosas no "son así", sino que somos nosotros los que tenemos impedido acceder a las cosas "de manera directa" en nuestro visionado. Esto es evidente para cualquier usuario de una plataforma de streaming cuando el ancho de banda de internet es insuficiente: la resolución baja y vemos una imagen deficiente, pero no porque la imagen lo sea de origen, sino que nuestro sistema de transmisión falla. Una vez más, establecemos la distinción entre la información misma que se presenta (lo que se dice, el enunciado, esta imagen deficiente en resolución) y la posición desde la que se presenta (las condiciones de la comunicación de la imagen, claramente sin deficiencias en la resolución original). Teniendo esto en cuenta es como podemos pasar a comprender el rol de la cámara como fundamento de la distinción entre ficción y no ficción.

shifts from investigating 'motion', 'motive', 'motivation' and 'motive force' toward explicit notions of agency, intention, purpose, and the use of a suitable rhetoric designed to move a spectator" (Branigan, 2006, p. 40).

5 No podríamos considerar que se establece un "puente", pues esto traería la connotación de que la cámara "acerca", a través de su registro, un objeto al espectador. El problema de ello es creer en una transparencia narrativa por parte de la cámara, cuando, como sabemos bien por documentales o películas de terror, los objetos más comunes pueden volverse sumamente ominosos precisamente por la brecha que introduce la cámara con su registro, volviendo extraño lo que es familiar.

6 El clásico para entender esta problemática en el cine de ficción es Bordwell (1985), y en el de no ficción, Nichols (2010). 


\section{MUNDOS PROYECTADOS Y MODELOS DE MUNDO}

La discusión sobre la distinción entre ficción y no ficción es sumamente extensa y compleja. Sin embargo, acotando este denso paisaje al considerar lo expuesto por la agencia de la cámara, la diferenciación de Plantinga (2010) se vuelve muy instrumental: la ficción propone mundos proyectados y la no ficción propone modelos de mundo. En sus palabras: "El mundo proyectado de una película es el qué; en el caso de la no ficción, el mundo proyectado es un modelo del mundo factual" (p. 84)7.

Toda película proyecta un mundo que propone (la diégesis). Las no ficciones no solo proyectan un mundo, sino que dicen que ese mundo proyectado es un modelo del mundo: la verdad que enuncian es la verdad con la que debe comprenderse la realidad fuera de la película. Mientras que la ficción plantea "supongamos que el mundo es así" al proyectar un mundo, en la no ficción se propone que "el mundo es así" al elaborarse un modelo del mundo ${ }^{8}$. Esto lleva a Plantinga (2010) a conclusiones con fuertes implicaciones, como cuando menciona (p. 38) que un documental no es una película que reproduzca lo real, sino que dice cosas sobre lo real.

Es decir que lo importante no es declarar si las cosas son o no verdad, pues enfrascarnos en esa discusión haría que perdiéramos de vista la reflexión sobre cómo aquello que consideramos verdad estructura, cambia, transforma e influye en el mundo en el que vivimos. Parafraseando a Plantinga, un documental no es una película que diga cosas ciertas, sino que dice que dice cosas ciertas. Esta reflexividad es la que permite pasar del primer al segundo paradigma expuesto anteriormente, es decir, pasar del objeto de la representación vs. representación del objeto al de representación del objeto vs. enunciación de esa representación.

¿Cómo se crea este modelo de mundo? Ciertamente no hay una distinción en el lenguaje: tanto en la ficción como en la no ficción, podemos hallar estructuras básicas como tomas, sonido intra y extradiegético, relaciones espaciales, temporales, gráficas y rítmicas de edición, etcétera. La distinción, siguiendo el camino trazado por el punto de vista de la cámara, se halla en el lugar que la cámara ocupa para construir la narración cinematográfica.

En las películas de ficción es común que, durante una conversación, veamos el rostro de los personajes en un plano-contraplano y luego detalles de su cuerpo; veamos que quienes allí aparecen empiezan a desnudarse y tener sexo sin molestarles la cámara que

7 "The projected world of a film is the what; in the case of nonfiction, the projected world is a model of the actual world" (Plantinga, 2010, p. 84).

8 Y en ese sentido, cuando veo una ficción, juego a que las cosas son así; mientras que cuando veo un documental, creo que las cosas son así. Por ello, cuando terminamos de ver un documental, tenemos un sentimiento de que "sabemos más". 
los está grabando; veamos que uno dispara a otro y el camarógrafo no se va corriendo temiendo por su vida. En esta variedad de situaciones, la cámara juega el mismo papel: un ente abstracto, fantasmagórico, que no parece tener presencia corpórea, pues sigue a los personajes sin que estos noten su presencia, habita en una dimensión paralela a ellos, no sigue leyes de la física ni parece inmutarse en las más adversas circunstancias.

Por su parte, en un documental, lejos de ser un ente fantasmagórico, la cámara es un objeto con presencia diegética, posee una existencia material que condiciona su labor. En una no ficción, las contingencias que tienen lugar sí ejercen una influencia en la cámara y su registro: no puede registrar un hecho delictivo si no es poniendo la vida del camarógrafo en riesgo, u ocultando su posición.

Tener esto en cuenta también afecta la brecha que señalábamos antes. Una vez que salimos del primer paradigma y entramos al segundo, hallamos una estrategia interesante del documental, que habita justamente en el intento de velar la brecha de esta distinción entre representación del objeto vs. enunciación de esa representación. En una película de ciencia ficción, la cámara se mueve a alturas, dimensiones y velocidades inalcanzables con el cuerpo humano. Si la ficción es un mundo proyectado, notemos que en el inicio de War of the Worlds (Spielberg, 2005), cuando vemos la simulación hecha con imágenes de computadora de microbios de una gota de agua, esas imágenes tienen un estatuto diferente de "la nave de la imaginación" de la serie Cosmos (Hanich y Holtzman, 2014), en la que el presentador nos aclara que vamos a ver una representación digital del universo.

Ahora, podría considerarse que esto contradice la idea de que la ficción propone un juego ("supongamos que el mundo es así") y la no ficción afirma categóricamente ("el mundo es así"), pues en el primer caso se presentan microbios (aunque sean imágenes digitales), y en el segundo se muestra una simulación de estrellas (porque son imágenes digitales). Sin embargo, solo se acrecienta esta brecha en tanto que, cuando vemos los microbios de la gota de agua en la película de Spielberg, jugamos a que estamos viendo microbios de esa película, mientras que cuando vemos las imágenes digitales en un documental asumimos que estamos conociendo cómo son las estrellas que habitan más allá de la serie de televisión.

Articulando esto con la presencia corpórea de la cámara, podríamos aventurar que, al menos en un sentido clásico y reconocido con facilidad, lo que la cámara de cine de la no ficción pierde en "libertad" que tiene en la ficción lo gana en cerrar la brecha entre la representación del objeto y la representación de la experiencia: tanto la cierra que incluso llegamos de vuelta a la primera brecha, por lo que enarbolamos con frecuencia una crítica del documental a partir de la brecha entre el objeto y la representación del objeto (diciendo que el documental no es "objetivo", que no considera "las otras perspectivas"), ignorando que un documental no solo habla de un contenido, sino también de la 
documentación misma (es decir, como no tenemos el objeto del documental, sino solo el documental mismo, únicamente podemos hablar de la brecha entre la representación y la representación de la enunciación misma).

En resumen, esto permite señalar al documental como aquella película en la que no tenemos acceso al tema mismo (el comportamiento animal, un caso de corrupción, la vida de una celebridad), sino al proceso de documentación de ese material, y con ello, la cámara de cine y su existencia material en este proceso cumplirían un papel esencial en la espectacularización del tema. Esta es una de las más fuertes consecuencias del planteamiento de Plantinga: cuando señala que un documental dice cosas sobre la verdad, no que dice la verdad, se refiere a que ningún documental muestra a un sujeto, sino que muestra que muestra algo y, a causa de ello, los documentales se vuelven películas sobre la verdad, en tanto apuntan a ese lugar, no películas verdaderas. El mismo autor sentencia con mayor fuerza que "un documental que hace aseveraciones sobre el mundo real no es menos documental si algunas (o todas) sus aseveraciones son falsas" (Plantinga, 1996, p. 321)

En otras palabras, el espectáculo de un documental no es el tema del documental, sino su discurso documental, su materialización a través de la cámara. A partir de ello podemos pasar a un tipo de cine caracterizado no por su tema o estética, sino por el rol que la cámara juega en su espectacularización, donde su presencia corpórea en la diégesis es lo que posibilita el espectáculo.

\section{EL FOUND FOOTAGE COMO UN ESPECTÁCULO SIN AUTOR}

El caso del found footage sería justo ese, donde la presencia corpórea de la cámara es lo que posibilita el espectáculo y, a su vez, es el tema del filme. Por ello, es un género que se nombra de acuerdo con el estatuto del producto en sí, y no de su temática (como el cine romántico, el de comedia, el de terror o el musical). El found footage es un género donde el tema y espectáculo es la cámara misma.

Mientras que en las ficciones la cámara suele ser un ente extradiegético (no reconocido por los personajes, una especie de fantasma invisible que les persigue), en el found footage se trata de una cámara "diegética", con presencia corpórea y material en la diégesis, suelta a la contingencia de lo que les suceda a los personajes. Hasta aquí, ciertamente, parece que hablamos de la cámara documental. Sin embargo, esto no alcanza a ubicar a los found footage como un tipo de documental, pues, a diferencia de este, el found footage se presenta como aquella película no editada, o no manipulada, que se exhibe tal

9 "A documentary that makes assertions about the actual world is no less a documentary if some (or all) of the assertions are false" (Plantinga, 1996, p. 321). 
cual fue encontrada, y esta es una razón fundamental de su distinción de lo que, durante el siglo xx y aún en autores contemporáneos, hallamos al hablar de found footage (más adelante expando este último asunto).

La diferencia entre el documental y el found footage es que en el segundo grupo notamos una especial atención en recordarnos la contingencia en la que habita esta cámara en esta diégesis: los personajes no solo saben que ahí hay una cámara, sino que muchas de sus acciones son para ella o para evitar seguir siendo grabados con ella, pausan la grabación, la dejan asentada, la cargan consigo o incluso pelean con el camarógrafo para detener la filmación. En un lugar insospechado encontramos una lógica y estética algo parecida: un video familiar.

Al entender estos videos caseros como un producto cinematográfico, se ubica una distinción no tan sencilla de explicar: una grabación con la videocámara familiar de la fiesta de cumpleaños de un niño difícilmente sería considerada un documental, aun si pasara algo extraordinario en ella, aun si fuera el único registro de algo que no sucederá de nuevo: no son elevados al estatus del espectáculo documental, se quedarán como "grabaciones", "registro audiovisual" o simples "videos de los hechos" (modo en el que se presentarían en un noticiero, por ejemplo). Un documental con entrevistas, dramatizaciones y material de archivo, editado y armado para presentar algún tema, sí es una película por sí misma.

Al ser elevados a la categoría de películas por sí mismas, los found footage tal parecen elevar el material de archivo a la dimensión del espectáculo cinematográfico. No es que estén conformados por material de archivo (lo que los haría cine de compilación), sino que el found footage mismo es material de archivo: es el material de archivo, en su cualidad de material "en bruto", vuelto la película misma.

Aquí podemos introducir una discusión histórica. Es cierto que durante el siglo xx el término found footage tenía una connotación de lo que hoy conocemos como cine de compilación. Dos ejemplos contemporáneos de ello son los documentales Ilusión nacional (Rubio, 2014) y They Shall Never Grow Old (Jackson, 2018). El cine de compilación sería aquel conformado total, o casi totalmente, por material de archivo, en el que este material suele llevar un proceso de reapropiación y, por lo tanto, resignificación. Así, un comercial de un dulce para niños, realizado en su momento como publicidad, es ahora usado para ironizar sobre un acto de corrupción en el fútbol mexicano (como en llusión nacional), mientras que una filmación de soldados riéndose al comer, realizada para alentar y aliviar el trabajo en el frente de batalla en su momento, solo añade más pesadumbre a su funesto destino, que conocemos 100 años después (como en Nunca llegarán a viejos). En este sentido parece ir la definición del Oxford dictionary of Film Studies:

Found footage. 1. Pre-existing film footage appropriated by a filmmaker and used in a way that was not originally intended. 2. A film comprised, in whole or part, of 
found footage. The term calls on the idea of a found object, or objet trouvé, as that term is understood in art history. Unlike the use of stock footage in documentary film, the term found suggests a less than respectful attitude to the prevalence of the film footage and to techniques of appropiation, collage, and compilation. (Kuhn y Westwell, 2012, p. 185)

Otros autores que encaminan su concepción del género en este sentido son Leyda (1964), Wees (1993), Godfrey (2007), Villegas (2009) y Baron (2014), quien ha escrito bastante sobre el tema y sobre el problema de este concepto con otros similares. Cineastas experimentales y videoartistas como Luis Ospina y Martin Arnold también son considerados realizadores de found footage bajo esta acepción.

También se podría citar al Found Footage Magazine, que se define a sí mismo como una revista académica que "ofrece contenido teórico, analítico e informativo sobre el uso de imágenes de archivo en prácticas de producción mediática"10. Lo que notamos es que la agencia autoral de una película found footage, en estos términos, "recicla" imágenes que son de archivo, es decir, imágenes cuya realización tuvo una intención distinta del uso que se le da en el nuevo filme.

Pero hay varias cuestiones muy importantes que harían que las películas que analizaré a continuación supongan, por lo menos, un tipo especial de found footage, que merece estudiarse con otros ejes que propondré (y que quizá haga que los casos que analizo más adelante sean found footage en pleno sentido de la palabra, y no cine de compilación o cine de archivo).

Una cuestión fundamental entre una película como Creep (Brice, 2014) e Ilusión nacional es que la primera no contiene créditos finales. Esta ausencia posiciona al filme en un entramado discursivo sumamente distinto a básicamente cualquier película que los incluya (al principio o al final), pues señala una falta de autoría. Olallo Rubio nunca niega que este material con el que conforma su película de compilación sobre el fútbol mexicano se haya transmitido en algún lado o esté alojado en algún banco de imágenes, pero tal parece que el video que vemos en Creep está sacado de la evidencia policíaca contra el criminal protagonista.

Los intertítulos explicativos al inicio de The Blair Witch Project (Myrick y Sánchez, 1999) y Hikikovlogs (Neos Nora, 2016), por mencionar filmes que se analizarán más adelante, pero donde también están incluidos fenómenos como Actividad paranormal (Peli, 2007), nos señalan que las investigaciones policíacas continúan tratando de hallar a quienes aparecen en estas grabaciones, o que se desconoce la fuente primigenia del material. La película misma se presenta como ausente de una finalización.

10 "Offers theoretical, analytical, and informative content that hinges on the use of archival images in media production practices". Más información en https://foundfootagemagazine.com 
Además, como veremos en los ejemplos, la agencia autoral inestable se manifiesta en las vueltas de cambio de autor a lo largo del producto audiovisual: durante su visionado, va cambiando quién es el que controla las imágenes, volviéndose estas imágenes de archivo para el nuevo autor (esto sucede especialmente en el caso del filme Creep).

Al carecer de un armado, pues se supone que así fue hallado el material" ${ }^{11}$, se tiene esta carencia de edición como sinónimo de una carencia también de agencia autoral: el found footage es una película que se presenta como si nadie la hubiera hecho, como si no se hubiera tenido control sobre ella. Como se ha mencionado, por supuesto que es común que aparezcan a cuadro los realizadores mismos (los camarógrafos), pero estos no tienen la agencia autoral sobre la obra que estamos viendo, pues, por algún motivo u otro, no se terminó. Esta es una gran diferencia con el cine de compilación antes mencionado, cuya autoría nunca se niega (¿acaso no hay hasta un manifiesto de Ospina donde se señala cuál es el motivo político tras su cine?).

Esta falta de agencia autoral es esencial para distinguir lo que un found footage es. Sería difícil que un cinéfilo casual medianamente versado confundiera las tomas que no se usaron en una película con la película finalizada (por algo son populares los bloopers y el material extra que había en los DVD y Blu-ray). La agencia autoral es autora de cada una de las tomas con las que se conforma la película y de la película misma (donde se ha atravesado el proceso de selección de una toma, su articulación con una toma anterior y la siguiente, etcétera). En tanto el found footage sería un material en bruto que fue así descubierto y, por lo tanto, carece de edición; hay una agencia autoral muy débil, casi inexistente. Por ello, en este caso, el espectáculo no es la película, sino la grabación de la película.

Como se verá en los análisis expuestos más adelante, los medios para ocultar o sutilmente burlarse de la agencia autoral en las películas found footage pueden llegar a ser muy sofisticados. Los obvios intertítulos explicativos antes mencionados son rupturas de la cuarta pared que resultan muy toscas en comparación con otros momentos cuando la agencia autoral y su relación con las expectativas de la audiencia hacia la película son burladas. Lo que se notará no es solo que el autor que esperamos falla, sino que otro autor toma su lugar: una agencia autoral que surge de un lugar que no puede determinarse con claridad, es decir, una agencia que emerge de un lugar que no alcanza a señalarse con las herramientas simbólicas que se poseen, que emerge de donde no debería emerger ninguna ${ }^{12}$.

11 No se puede evitar recordar las estrategias de publicidad de El proyecto de la bruja de Blair, y cómo estas afectaron la vida personal de su protagonista. Para más información véase el análisis del filme en la siguiente sección de este texto.

12 Esta idea viene por inspiración del libro de Comanducci (2018, p. 33), donde se contrapone la agencia que puede señalarse como la que voluntariamente ejecuta una acción, y la agencia que se manifiesta donde se suponía que no hubiera una. 
Esta caracerística es la que también sacaría al found footage de un muy lodoso terreno donde podríamos creer que cae: el del falso documental. Intentar resumir lo complejo de este campo y sus diferencias con el documental sería una tarea absurda para este texto y sus propósitos ${ }^{13}$, pero lo que resulta evidente es que, "falso" o "verdadero" (dimensiones que caricaturizan las consecuencias del falso documental, y que son una pista muy falsa y superficial para comprender el tema), la distinción entre el falso documental y el found footage es que el primero sigue gozando de una agencia autoral estable (se sabe quién lo hizo, incluso en uno de terror como Lake Mungo, Anderson, 2008), mientras que el segundo sigue carente de ello.

Entonces, cinco son los ejes por los que se podemos caracterizar al found footage: (1) la cualidad corpórea de la cámara como objeto al interior de la diégesis, y que lo pondría en contraposición a la cámara de la ficción; (2) la supuesta falta de edición y armado, que le valdría la connotación de suerte y azar o falta de intención que hay en su nombre (y que lo ubicaría en contraposición al documental o al cine de compilación), donde sí hay un proceso de edición, selección y control sobre la grabación; esto lleva a entender el found footage como (3) una espectacularización de la grabación, al dejar el estatus de "video casero" y convertirse en una "película", acompañada de diversas estrategias transmedia (que serán ejemplificadas más adelante); (4) a raíz de la carencia de edición, la falta de una agencia autoral sólida, que funcione igual a como funciona en la ficción y la no ficción, y que se manifiesta tanto en el propio contenido (intertítulos que explican el origen de estas grabaciones, realizadores incapaces de llevar a buen camino el proyecto) como en la estructura y forma de la narración (donde la agencia autoral, la que dirige la narración misma, es inestable); $y$, finalmente, la falta de una agencia autoral sólida se traduce en que el sujeto que enuncia no tiene control sobre sus enunciados, por lo que termina en una posición vulnerable respecto a (5) una mirada fantasmal que le vigila (fantasmal no en el sentido de sobrenatural, sino en el sentido de no poder colocarla con facilidad en otro individuo al interior de la diégesis, por lo que responde más bien al Otro que regula la interacción entre los otros). Es sobre estos ejes que se construyen los análisis que se desarrollan a continuación.

Se llega así a una definición del found footage: aquella película cuya cámara constituye un ente corpóreo en el espacio diegético (a diferencia de la ficción), pero que no tiene una cualidad de producto audiovisual terminado (a diferencia de la no ficción) en tanto "fue encontrado". En consecuencia, el found footage es una película donde el material protocinematográfico, la filmación, es elevado al estatus de espectáculo cinematográfico, la película, sin pasar por una agencia de edición, desestabilizando a la agencia autoral.

13 Para conocer una primera aproximación al problema, revisar Aguilar (2020). Ahí también se encuentra una discusión entre el término falso documental y el mockumentary, común en la literatura en inglés, pero superficial para entender el fenómeno. 


\section{ANÁLISIS DE CASOS}

\section{El espectáculo de la bruja de Blair}

Un volante donde se pedía información para encontrar personas desaparecidas muestra los rostros de tres jóvenes, quienes fueron vistos por última vez en las inmediaciones del bosque de Black Hills. En un documental hecho para televisión, previo al estreno en salas comerciales de la cinta, hermanos y amigos de los desaparecidos, así como policías y expertos en brujería, dan sus interpretaciones de los hechos. Una página web, algo bastante novedoso en ese entonces para películas, mostraba reportes policíacos y entrevistas en noticieros. Todo esto es parte de la campaña de promoción que volvió sumamente popular una película durante su estreno y discusiones posteriores: The Blair Witch Project.

Un intertítulo nos aclara al principio del filme qué es lo que vamos a ver: unos jóvenes desaparecieron en octubre de 1994 y, un año después, se halló el metraje de lo que grabaron. No hay más información sobre las imágenes que continúan. No hay cintas identificadoras que indiquen días, horas o lugares, o nombres de quienes aparecen a cuadro.

Lo que le hace falta a ese intertítulo es que este es el metraje que grabaron y que ha sido editado para su presentación. Lo que intenta ocultar con esta falta de información es la agencia autoral: ¿quién y por qué hizo esta película? ¿Quién deja corriendo la voz de Heather leyendo una historia con tomas del bosque de Blair? ¿Quién va montando los metrajes de las dos cámaras a lo largo de la película, como el plano y contraplano de Joshua y Heather grabándose mutuamente con dos cámaras distintas (figuras 1 y 2)? Esta duda sobre la autoría de la película, la cual nunca queda aclarada, es una de sus mayores herencias en los found footage que le siguieron.

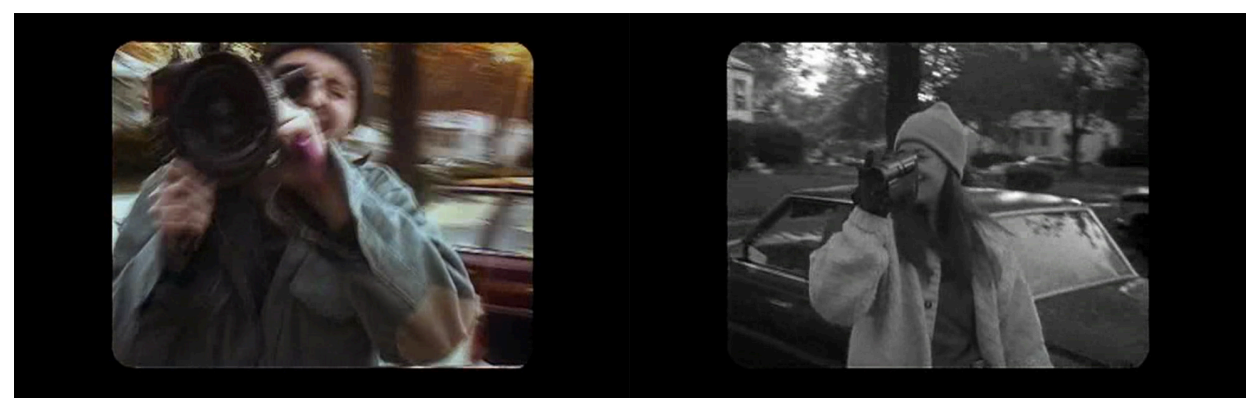

Figura 1 y figura 2. The Blair Witch Project

Fuente: Myrick y Sánchez (1999, 00:01:38, 00:01:42)

Uno de los temas más recurrentes en The Blair Witch Project es la serie de problemas al filmar un documental: inexperiencia en el manejo del equipo, falta de profesionalismo 
y de compromiso de todas las partes, excentricidades de los entrevistados, inclemencias del clima para las que no se está preparado, perder el mapa del lugar remoto en el que se encuentran. Todo esto termina exponiendo a Heather y su equipo como incapaces de llevar a cabo la tarea que se han propuesto. Rebajar la capacidad de agencia y autoridad del realizador del documental es un motivo recurrente en esta película, y en muchos found footage.

Al principio de la cinta se menciona como parte de la leyenda que la bruja hacía a sus víctimas mirar a la pared, mientras esperaban su turno fatal. Se hace un guiño a esto hacia el final, ante la incapacidad de sus realizadores: Heather graba a su compañero mirando a la pared y grita, cae la cámara pero esta mira hacia otro lado (última toma del filme), precisamente para no ver lo que le sucede a Heather, como si no solo ella perdiera control sobre la cámara, sino que, además, la propia bruja (una mirada que la vigila) lo adquiere.

La campaña de marketing de la película es por sí misma un caso de estudio sobre el poder para construir narrativas transmedia antes de las posibilidades de lo digital. Nos hace cuestionar afirmaciones como la de un público "más sofisticado" a principios de este siglo ${ }^{14}:$ ni siquiera los créditos al final del filme, que reconocían a directores de marketing y diseñadores de audio, lograron persuadir a gente que envió cartas de condolencias a la madre de Heather Donahue por la muerte de su hija ${ }^{15}$.

El problema de la autoría se agrava en varias dimensiones: los directores (Sánchez y Myrick) no estuvieron físicamente presentes durante la filmación de la mayoría de las escenas al interior del bosque, sino que entregaban a cada actor una serie de instrucciones de cómo actuar ante los demás y hacia dónde caminar al día siguiente. Esto abrió mucho espacio para la improvisación y confusión. Los sonidos de niños gritando y la tienda de acampar moviéndose fue una genuina sorpresa para los que ahí dormían.

El éxito comercial de la cinta no es un asunto menor: se calcula que cada dólar invertido en ella se multiplicó casi por diez de recaudación, convirtiéndola en una de las películas más taquilleras de la historia en función del costo/recuperación ${ }^{16}$. La influencia de la película en el cine de terror de principios del siglo xxı es innegable, así como lo rápido que se agotó el formato hasta volverse repetitivo, fastidioso y poco original.

14 Estas afirmaciones sobre la sofisticación de la audiencia del nuevo siglo fueron expuestas y criticadas con mayor profundidad en Aguilar (2020).

15 Para más información de esta y otras anécdotas post-Blair en la vida de la protagonista, revisar https://www.gq.com/story/the-blair-witch-projects-heather-donahue-is-alive-and-well

16 Información detallada del éxito comercial se encuentra en https://www.boxofficemojo.com/release /rl2269611521/ 


\section{El espectáculo negado: Domingo}

El cortometraje Domingo (Vigalondo, 2005) es muy sencillo en factura y producción, pero revela un gran dominio del lenguaje cinematográfico y, en particular, de la naturaleza espectacular del found footage.

La cinta consta de una sola toma, con un movimiento. Inicia con un plano abierto hacia el cielo, donde hay una nave alienígena propia de la estética de ciencia ficción de los cincuenta (figura 3). Abajo se nos indica la hora y día de grabación, como en las videocámaras caseras. Mientras se sostiene este plano durante dos minutos, la cámara tiene detrás de sí a una pareja de novios discutiendo, ya que él ha estado grabando durante cuatro horas al objeto en el cielo, mientras que ella le reclama por estar usando las cintas de sus vacaciones en Turquía. Como comentan en medio de sus argumentaciones, el platillo no se ha movido ni ha emitido un sonido en todo este tiempo.

La discusión escala hasta que ella decide irse, por lo que él se pone de pie y la sigue hasta el auto. Aquí es donde tiene lugar el único movimiento de cámara del cortometraje: al levantarse golpea la cámara por accidente, y esta cae hacia atrás, mostrándolos ahora a ellos reconciliándose y dándole la espalda al platillo volador (figura 4). Este movimiento es accidental dentro de la diégesis de la película, pero tiene la función de privarnos del espectáculo nuevamente: ráfagas de viento y un sonido psicodélico provocan que los personajes dejen de hablar y dirijan su atención a donde se encuentra la nave, diciendo que es lo más increíble que han visto en su vida.
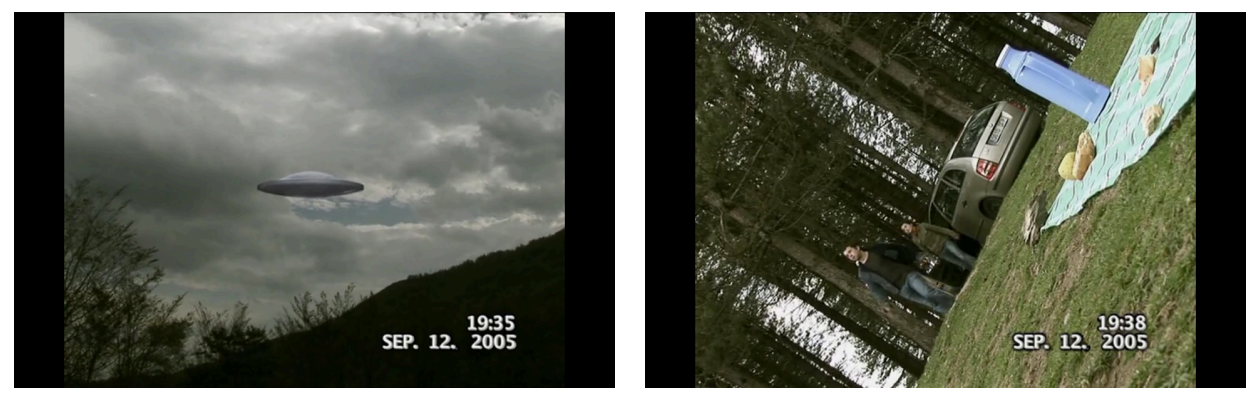

Figura 3 y figura 4. Domingo

Fuente: Vigalondo (2005, 0:00:06, 0:03:17)

En Domingo, se hace explícita la división y diálogo que sostienen los espacios dentro y fuera de cuadro. Esto remite a nuestra comprensión sobre la tensión entre el objeto de la representación (la nave espacial), la representación del objeto (la grabación: composición, sonido, ángulo, plano, color) y la enunciación de esa representación (nuestra posición sujeta a la contingencia del dispositivo). Como señalé en la discusión teórica previa, la brecha entre los primeros dos no sería lo interesante por estudiar (ya que, 
al no haber estado ahí, poco podemos hacer en analizar el objeto mismo), por lo que deberíamos considerar la brecha entre los otros dos (la cámara es la condición de posibilidad de nuestra experiencia de visionado). Para comprender esto, puede resultar útil el diagrama de la figura 5.

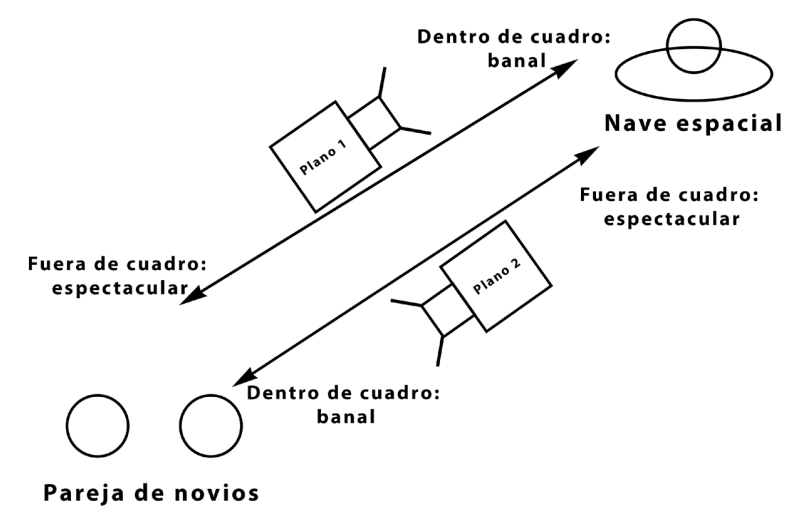

Figura 5. Diagrama de Domingo

Elaboración propia

Considerando que es una sola toma, pero hay dos planos en ella, podemos claramente diferenciar dos espacios que alternan estar dentro y fuera de cuadro. La primera parte de la toma parece espectacular los primeros segundos, pero se torna monótona y banal cuando pasan los minutos y la nave no hace nada, por lo que nos interesamos más en la discusión que tiene lugar tras de nosotros, pero que no podemos ver; es decir, se nos niega el espectáculo que sí queremos ver (la divertida discusión de la pareja) por estar viendo una banalidad (la aburrida nave espacial). Con el movimiento "accidental", el procedimiento se invierte, pues ahora nos parece banal y cursi la reconciliación y nos perdemos el espectáculo de la nave.

En ese sentido, Domingo nos recuerda que lo que está fuera de cuadro le da siempre sentido a lo que está dentro de cuadro. También nos muestra que la lógica del found footage es la del espectáculo, aun cuando no lo muestra directamente: el espectáculo del cortometraje no es la nave alienígena o la discusión de la pareja, sino cómo se nos niega, con un simple y "accidental" movimiento, el acceso a lo espectacular. Lo espectacular y lo banal, entonces, parten de una dialéctica entre el dentro y el fuera de cuadro.

\section{Una película en una película en una película: ¿quién es el creep en Creep?}

Un camarógrafo desempleado, Aaron, cuenta a la cámara que respondió un aviso en internet que anunciaba que pagarían muy bien por un día de filmación. Al llegar a la casa donde nadie responde, nota un hacha en el jardín. Regresa a su auto a esperar que 
aparezca alguien, cuando se le sorprende con uno de los primeros jump scare de la película: es Josef, el excéntrico hombre del aviso, parado junto a su auto.

Creep (Brice, 2014) está llena de estos jump scare, pero en un tono crítico: a diferencia de los de una película de terror habitual, este recurso no trae la aparición de un espectro, monstruo o asesino, sino que siempre son bromas de Josef hacia Aaron. Ya sea él apareciendo detrás de un tronco o una máscara que sorprende al protagonista, el obsesivo uso de la técnica deriva en volver inmune al espectador y, con ello, notar lo patético de usarlos para una película de terror.

Tras las primeras escenas y una caminata por el bosque, cargada de las excentricidades de Josef (le pregunta si vio el hacha en el jardín y si creyó que lo asesinaría con ella), ambos terminan en un restaurante. Allí tiene lugar el primer momento de socavamiento de la agencia autoral, ya que se invierten los papeles y el documentalista será interpelado por el sujeto del documental: Josef le pregunta a Aaron si hay algo muy vergonzoso que quisiera compartir ante la cámara, así que le pide que se la pase para que ahora él (Josef, sujeto del documental) lo grabe (a Aaron, director del documental). Este cambio súbito claramente pone más incómodo a Aaron, pero aun así narra una anécdota muy personal. Para sentirse más acosado y vulnerable, Josef le confiesa que le estuvo tomando fotografías a lo lejos cuando le vio llegar a la casa.

La película avanza y, tras un violento incidente en la cabaña, se nos hace creer que Aaron fue asesinado y que ahí termina la película. La siguiente toma es de Josef cargando bolsas de basura y empezando a cavar un hoyo en la tierra (figura 6). La imagen se congela, y la cámara gira revelando que una segunda cámara grababa la imagen de una pantalla: esa toma de Josef cargando pesadas bolsas de basura, que creíamos que era Aaron despedazado, era una toma dentro de la diégesis del filme, grabada por el propio Aaron, así que lo que veíamos era una grabación de una grabación. Aaron está vivo y bien, y nos cuenta que, tras escapar y regresar a casa, empezó a recibir por correo este tipo de cintas (figura 7). Se creía que Aaron había perdido control sobre la cinta, pero el realizador lo recupera para mostrar que sobrevivió a su encuentro con el sujeto de su documental y, en consecuencia, él mismo se vuelve ahora sujeto de su propio documental.
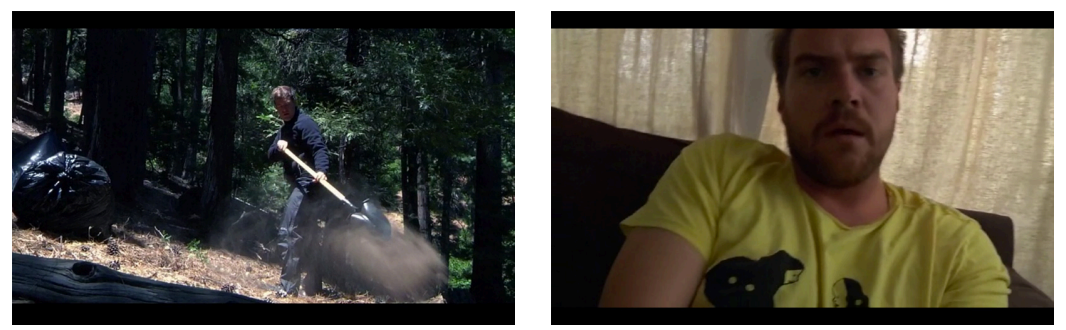

Figura 6 y figura 7. Creep

Fuente: Brice (2014, 0:49:30, 0:49:39) 
El acoso de Josef hacia Aaron se vuelve cada vez más grave, hasta que en un último video le pide disculpas y le ruega por su ayuda para terminar con los obvios problemas mentales que tiene. Aaron, ingenuamente, asiste a una reunión pactada frente al río $y$, para tener evidencia de lo que le pase, deja una cámara grabando desde el interior del auto hacia el punto de reunión. Camina hacia la banca frente al lago; una figura se aparece tras él en silencio, saca un hacha y lo ataca por la espalda (figura 8).

Aquí la imagen vuelve a congelarse y cambia de agencia autoral. La cámara panea para mostrar que esto también era una grabación dentro de la diégesis del filme, y que es Josef el que está viendo el video, preguntándose por qué Aaron fue tan ingenuo como para no voltear hacia atrás y ser presa tan fácil, cumpliendo, además, la intriga de predestinación sobre el uso del hacha, mencionada en dos ocasiones previas (figura 9). Así, Josef se revela como la mente que estuvo manipulando la narración todo este tiempo, creando una película más para su colección de víctimas que guarda en un clóset. Para continuar empujando esta ironía, el último jump scare del filme es uno que se provoca Josef a sí mismo: el Josef de la grabación del asesinato de Aaron sorprende al Josef que estamos viendo que edita el filme.
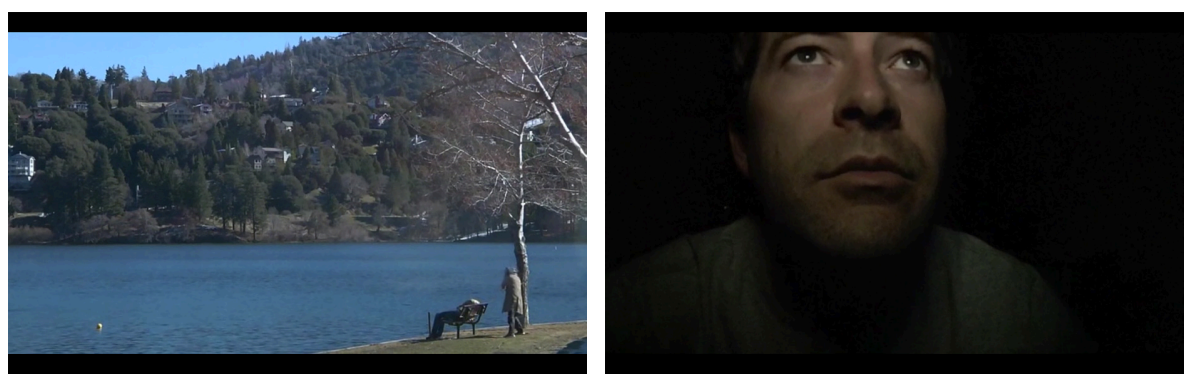

Figura 8 y figura 9. Creep

Fuente: Brice $(2014,1: 12: 19,1: 12: 27)$

La película está dividida en tres partes, diferenciadas por los dos cambios en la agencia narrativa que demuestran que lo que estábamos viendo previamente era en realidad una película dentro de otra película, como se señala en el esquema de la figura 10.

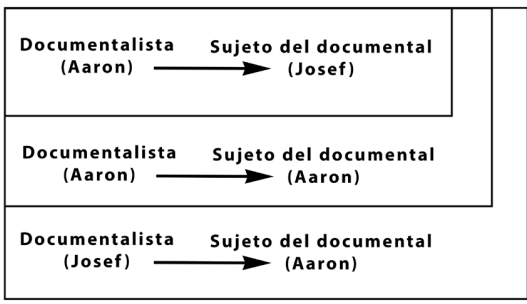

Figura 10. Diagrama de Creep

Elaboración propia 
El rectángulo (o pantalla) más pequeño es con el que inicia la película: Aaron es el realizador de un documental sobre Josef. Tras la confrontación física entre ambos y el video de Josef enterrando unas bolsas, nos damos cuenta de que Aaron sobrevivió. El siguiente segmento de la cinta es él lidiando con el acoso de Josef, lo que supone el segundo rectángulo, y que envuelve al primero, pues la película siempre estuvo incluida en él (Aaron siempre tuvo el poder de la narración, pues vemos que sigue vivo). Por último, el tercer y más amplio rectángulo es en el que los anteriores dos estuvieron todo el tiempo, ya que desde un principio era Josef el documentalista y su sujeto era Aaron: es el propio Josef el que está montando la película y al final se erigió como quien tenía la agencia narrativa y autoral sobre la misma.

La inversión de roles de documentalista y documentado en Creep es indicativo de una lógica del acoso subyacente a todo proyecto documental, que los sujetos del documental tratan de revertir. Esta lógica hace que un documental no solo destape secretos de su sujeto, sino que en sí mismo constituye la presentación del voyerismo de su realizador. El documental habla tanto de su realizador como de lo que sea que registra. Por eso Aaron se incomoda tanto cuando ahora él está siendo grabado: acostumbrado a estar detrás de la cámara, siente el peso y poder que acostumbra tener ahora vuelto en su contra, la mirada voyerista que se le regresa y con la que debe ahora lidiar.

\section{La vigilancia autoimpuesta: $\mathrm{V} / \mathrm{H} / \mathrm{S}$}

Para extender por otra dimensión la agencia autoral, un buen ejemplo resulta $V / H / S$ (Bettinelli-Olpin et al., 2012), un found footage conformado por varios found footage dirigidos por diferentes directores. Un grupo de jóvenes que pasan sus tardes acosando mujeres en la calle y vandalizando edificios son contratados para entrar furtivamente a casa de un hombre para robar una cinta VHS. Allí encontrarán el cadáver del dueño de la casa, así como decenas de otras cintas, que por curiosidad comenzarán a ver. Cada una de ellas cuenta una historia distinta, cinco en total. Con motivo de la discusión, vale detenerse en el primero y el tercero de estos episodios.

El primero resulta ser el metraje grabado con unos lentes que tienen una minicámara oculta incorporada, de modo que todo este found footage es en casi todo momento el POV de un joven que, con sus dos amigos, va a ligar a un bar una noche. Este furtivo sistema de vigilancia tiene el objetivo de grabar un video porno a expensas de la ignorancia de alguna desafortunada joven, para venderlo en internet (figura 11). Llegan al cuarto de un motel con dos chicas, una de ellas cae dormida después de tanto alcohol. Uno de los jóvenes se acerca a la otra, que ha estado muy callada todo el tiempo. Ella empieza a atacarlos, mordiéndoles y abriéndoles el pecho. Del mismo modo que es testigo el joven con los lentes, somos testigos nosotros, a partir de este POV. 


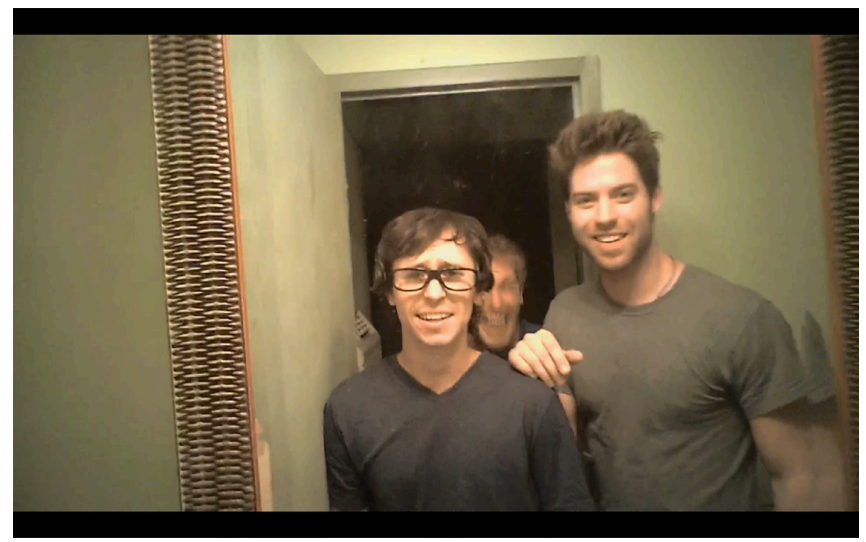

Figura 11. V/H/S

Fuente: Bettinelli-Olpin et al. (2012, 0:11:46)

Esta cinta nos recuerda que, para entender la sociedad contemporánea de la vigilancia, el found footage puede ser una importante herramienta. Es curioso este sistema de vigilancia que se pone el sujeto, a causa del cual tiene ese infortunio que vemos nosotros: mientras que nos quejamos y preocupamos por los ocultos sistemas de vigilancia gubernamentales, también abrazamos con júbilo las tecnologías de vigilancia de Silicon Valley en las que podamos poner nuestras manos.

El tercer cortometraje cuenta la historia de otro grupo de jóvenes, dos hombres y dos mujeres, que van a pasar el día junto al lago en un bosque. Allí, una de ellas confiesa que estuvo en ese lugar antes, donde fue testigo de asesinatos inexplicables de los que solo ella logró escapar. Por supuesto, la historia se repite, y los jóvenes empiezan a morir a manos de un asesino que se manifiesta a través de glitches en la imagen de la videocámara, cortando el cuello de sus víctimas (figura 12). La joven es testigo nuevamente de las muertes, hasta que ella misma es atrapada por el ente interdimensional, que habita en la total virtualidad y que, además, le arrebata la cámara para filmar la muerte de ella. Es en la brecha que divide la realidad de la virtualidad, manifestada en el glitch, donde aparece el ente homicida.

Este asesino que solo es posible ver gracias a que la cámara nos señala otro modo en que se mina la agencia autoral en el found footage: no se puede tener control por todo lo que se filma, e incluso hay alguien que nos mira todo el tiempo, estemos o no filmando. 


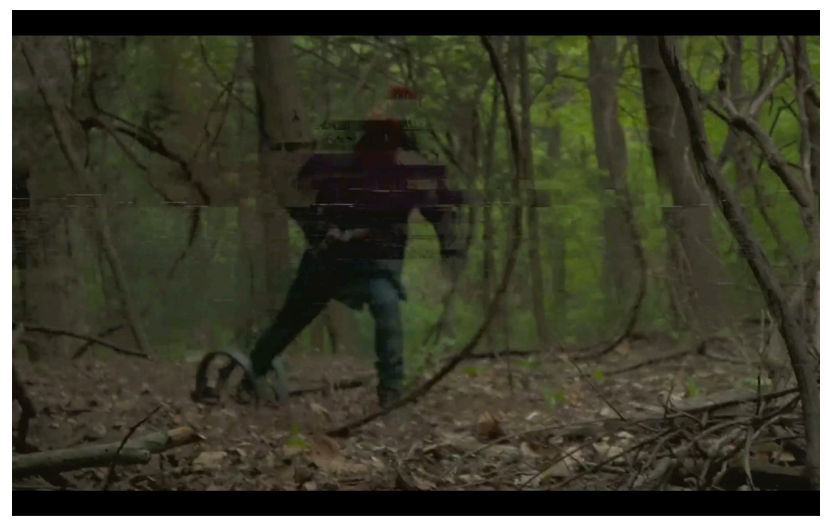

Figura 12. V/H/S

Fuente: Bettinelli-Olpin et al. (2012, 1:10:46)

\section{Siempre mirando, siempre siendo visto}

A mediados del 2009, en YouTube empezaron a cargarse los episodios de una serie web en formato found footage llamada Marble Hornets. En ellos, con la ayuda de intertítulos, se narra la historia de Jay, quien trata de averiguar lo que le pasó a su amigo Alex cuando grababa una película hace años y que, desde que abandonó el proyecto abruptamente, se ha recluido de la sociedad. Regresando sobre sus pasos y revisando el material, Jay descubre una extraña figura que acecha en los videos: un hombre muy alto, delgado, vestido con saco y pantalón negros, con la cabeza blanca y sin rostro. Esta figura es conocida en el mundo de internet como Slenderman.

En el 2015, la serie web fue adaptada en una película found footage: Always Watching: $A$ Marble Hornets Story (Moran, 2015). Sus protagonistas son un grupo de trabajadores de un canal de noticias: Milo, el introvertido camarógrafo, y su compañera de trabajo de la que está enamorado, Sara, la atractiva reportera del noticiero, y Charlie, nuevo integrante que completa el triángulo amoroso.

Milo empieza a notar que las cámaras con las que trabajan muestran fallos de glitch, en los cuales se asoma Slenderman, que es invisible ante el ojo desnudo, pero no ante el visor de la cámara. Milo se obsesiona y, presa del pánico, empieza a instalar cámaras y proyectores en su casa. Cuando logra convencer a Sara y a Charlie de que Slenderman existe, los tres intentan escapar, pero todos terminan muriendo en el bosque.

Lo que vuelve interesante a la película es el doble juego de su título: Always Watching (Siempre mirando) se entiende en dos sentidos: (1) Slenderman está siempre mirando, a pesar de que no podamos mirarle, pero también (2) el intento de Milo de mirarlo termina siendo siempre mirado por alguien más que Slenderman, por la tecnología de vigilancia con la que se rodea él mismo. 
La brecha de dieciséis años que separa a The Blair Witch Project de Always Watching pesa mucho al hablar de la vigilancia: mientras que en la primera se alterna solo lo grabado por dos cámaras, en Always Watching hay muchas cámaras que desde distintas lógicas y posiciones registran los hechos: las cámaras del noticiero, las cámaras de los celulares, las cámaras de vigilancia del estudio (figura 13). Todos estos puntos de vista son mostrados a lo largo de la película, y abundan los momentos en los que los personajes no ven que son mirados; es decir, en las pantallas aparece Slenderman, pero no hay nadie allí para verle, más que el espectador (figura 14). A pesar de todo este complejo sistema de grabación, los personajes no pueden escapar del fatal destino. En estas primeras dos décadas del siglo, la evolución del found footage nos señala la evolución en los sistemas de vigilancia sobre el individuo.

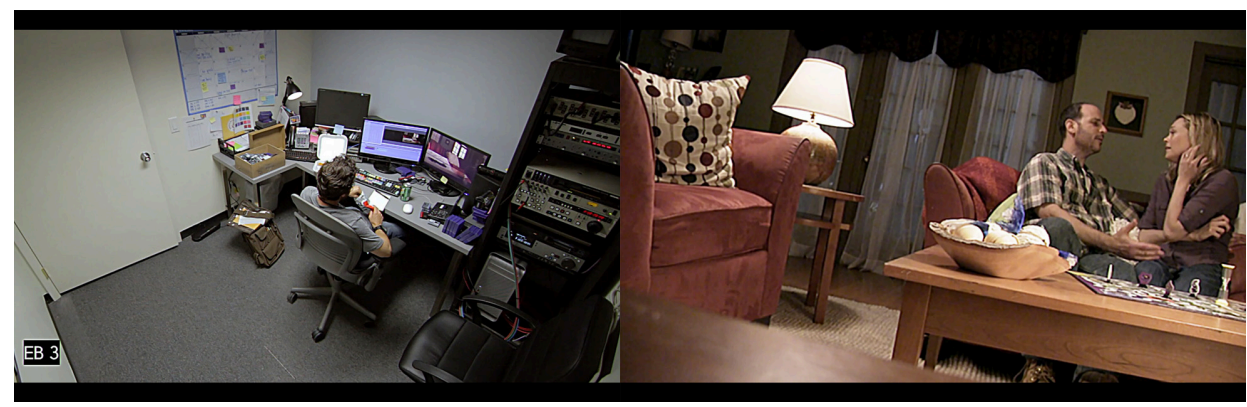

Figura 13 y figura 14. Always Watching: A Marble Hornets Story

Fuente: Moran (2015, 0:20:44, 0:23:10)

Slenderman solo puede ser visto a través de la falla en el código (el glitch en la pantalla), pero sus efectos pueden ser experimentados fuera del código (en los cuerpos de los personajes). A causa de esto, los personajes necesitan ver su entorno a través de las pantallas, ya que sus propios ojos son inútiles para ello. Necesitan, para sobrevivir, volverse cyborgs, y sus nuevos órganos son la videocámara, el teléfono celular y el proyector, sin los cuales no pueden defenderse de una figura que habita en la interdimensión del código.

\section{Múltiples autores, múltiples máscaras: Hikikovlogs}

El cortometraje Hikikovlogs (Neos Nora, 2016) aprovecha una confusión sobre su autoría para plantear comentarios sobre la agencia autoral del contenido de la web. Se trata de la recopilación del material de un videoblog en el que un joven, que se presenta a sí mismo como Hikikovlogs, nos introduce en su complicado entorno familiar. Vive con sus dos abuelos; la primera vez que los vemos interactuar, ellos le dan una paliza, llamándolo depravado por un hecho que no presenciamos. A pesar de que solo vemos 11 videos, los números varían del 1 al 18, sin que se nos explique la razón de la ausencia de los demás. 
Esta falta de videos se hace más confusa con el reconocimiento en la propia obra, a través de intertítulos, de al menos cuatro agencias autorales: (1) un autor explícito, el protagonista del videoblog, Hikikovlogs; (2) el autor citado por los intertítulos, "usuario anónimo", que es quien subió los videos que son la base del armado que estamos viendo; (3) un autor implícito, que es el propio editor de la versión que vemos y que impone una estética particular, con la música extradiegética que sirve de puente entre los videos, así como con los intertítulos donde se explica el origen y confuso camino de los mismos; y (4) los autores potenciales, que se indica que posiblemente modificaron el contenido, además de los tres anteriores.

A lo largo de los videos, Hikikovlogs nos presenta a un muchacho del que está enamorado, y con el que tiene serios problemas para al menos presentarse. La primera vez que lo vemos es cuando le pide la hora en un parque, portando su característica máscara azul con la que nos priva de verle el rostro, al menos en un principio. Otras escenas en apariencia triviales incluyen a él bailando en ropa interior, practicando besos y contándonos cómo pasará su primera cita con su amor platónico. Cuando este no es correspondido, el videoblogger decide secuestrarlo, atarlo a una silla y seducirle. Cuando su víctima intenta escapar, lo ahorca para así mantener su cadáver junto a él y luego revelarnos que lo mismo ha hecho con sus abuelos.

Hikikovlogs recurre a varias cámaras para continuar con su historia, ya sea dentro de la fortaleza emocional que el personaje encuentra en su cuarto o en el parque de una tranquila ciudad donde se enfrenta al amor de su vida. Usando la cámara de su laptop y la de su tableta electrónica, y alternando los azules del cielo abierto con los rojos de su habitación cerrada, se construyen espacios que alternan amenaza y seguridad, inocencia y malicia (figuras 15 y 16 ).

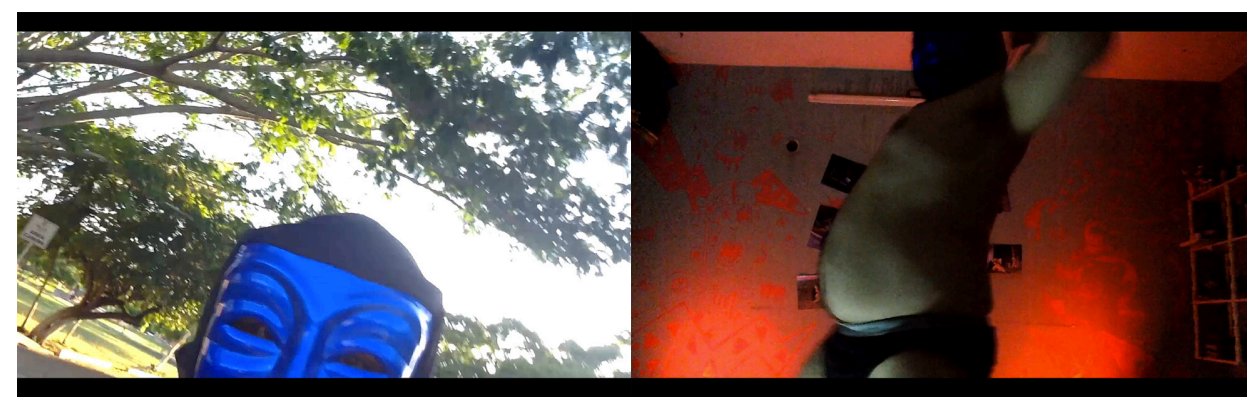

Figura 15 y figura 16. Hikikovlogs

Fuente: Neos Nora (2016, 0:10:39, 0:11:39)

Como varios personajes criminales, Hikikovlogs sigue la lógica de la máscara no solo como pared para ocultar su rostro a testigos, sino como poder simbólico sobre las víctimas. Se la quita para decirnos que ya no tiene miedo, pero la tiene puesta al 
secuestrar a Fernando, y se la saca por última vez hasta que ya lo tiene atado a la silla. Mientras la música ironiza el encuentro de amor y el asesinato, caemos en cuenta que Hikikovlogs no usa la máscara para ocultar su rostro, sino para mostrar su verdadero rostro, el del asesino que es.

Esta lógica de doble máscara es eco de la múltiple máscara del autor del cortometraje, que sigue la lógica del reciclaje y reutilización del contenido de la web. Viviendo incapaces para decidir dónde empieza y termina la autoría de una obra, poner un límite a esto hace que estemos ya, voluntaria o involuntariamente, adquiriendo agencia autoral sobre la obra.

\section{Atroz y la objetivación de la mirada}

La última obra por analizar, Atroz (Ortega, 2015), nos muestra las cintas grabadas por un asesino serial en la Ciudad de México, y fue señalada, tanto en su campaña de marketing como por la crítica, como "la película mexicana de terror más violenta de la historia"17.

Es importante la locación, porque hay un marco en el que se pretende dar sentido a la historia, que es evaluado durante la primera secuencia, y se trata de vistas documentales de las calles de la capital mexicana: basura, prostitución, pobreza, desempleo, inseguridad y tráfico, alternándose con los créditos iniciales y estadísticas sobre la corrupción e impunidad que se vive día a día en México. Autos pitando, gritos de la muchedumbre, sirenas de policías y ambulancias, así como noticieros y reportes en la radio, son la pista de sonido que acompaña las imágenes, en una estética muy similar a los documentales de sinfonías de ciudades de principios del siglo pasado. Aquí se puede hablar de una sinfonía de la caótica metrópolis contemporánea, rebasada por sus problemas diarios que no paran de crecer.

Este documental de la ciudad se interrumpe por la historia de ficción, que es la de un agente policial que da con una pareja de sádicos asesinos que graban sus crímenes. De ese modo, y a lo largo de la película, se irán alternando estas escenas de ficción con metraje encontrado. Este segundo es sobre el que se comentará a continuación.

El desfile de espectáculos salvajes incluye la tortura y asesinato de una persona travesti y una prostituta, así como videos de cuando el propio protagonista era más joven y, junto con su hermana, torturó y asesinó a sus padres. La edición de estas escenas no solo incluye jump cuts a lo largo de las tomas, sino también glitches de la imagen y una pista de sonido cuyo volumen sube y baja. Estas alteraciones de la imagen y el audio van desde hacer más "soportable" el sadismo al ocultarlo, hasta hacerlo más insoportable al espectacularizarlo.

17 Una crítica que hace referencia a lo apropiado de su eslogan comercial puede encontrarse aquí: http://www.revistacinefagia.com/2015/11/atroz/ 
Entre estas escenas hay una lógica de expansión de los límites de la mirada de la cámara en su articulación con el cuerpo. Se distinguen tres interesantes POV: (1) la cámara en el puño, que viaja de la cercanía con el torso del golpeador al rostro de la víctima (figura 17); (2) el POV propio del cine pornográfico gonzo, que mantiene la lógica del torture porn en la cinta (figura 18); y (3) la toma del dildo con púas que se introduce en el ano del padre (figura 19).

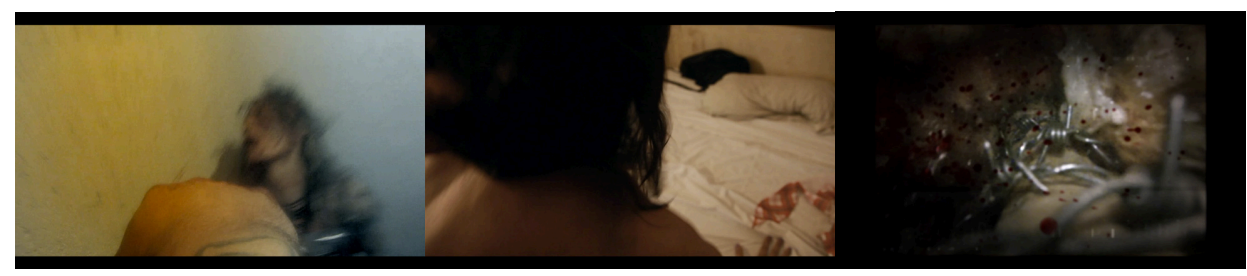

Figura 17, figura 18 y figura 19. Atroz

Fuente: Ortega (2015, 0:16:36, 0:30:20, 1:00:07)

Esta última toma es particularmente relevante no solo por lo chocante, efecto al que contribuyen la edición de sonido y las gotas de sangre que impregnan la pantalla. Cuando el protagonista pone a su madre el arnés con el dildo, al que se le enrollan púas, y la obliga a penetrar a su esposo, monta también una cámara miniatura sobre el dildo. Este pene de plástico que tiene montada una cámara y púas a su alrededor, y que penetra analmente al padre, supone el modo más brutal en el que la mirada se objetiva, se transforma en un objeto dentro de la diégesis (vía la cámara) para inspeccionar las grietas de la figura paterna, totalmente minada a modo de venganza.

Así como la cámara se adentra en los oscuros rincones del cuerpo, así la cámara del found footage es un recurso para adentrarse en los oscuros rincones de la traumada psique del personaje, que también es, precisamente como psique del individuo, sintomático de la psique de la sociedad en la que habita. Por ello también somos testigos de la salvaje violencia intrafamiliar con la que el protagonista vivió su desarrollo sexual en la adolescencia.

La cinta no trata solo de la violencia del personaje, sino de la violencia del personaje que está asentada en la violencia del entorno. Aquí es donde se distinguen, entonces, las dimensiones de violencia subjetiva y objetiva: la violencia subjetiva es la del feminicida sádico que asesina personas travestis y prostitutas, pero la violencia objetiva es la que provoca esta devastadora consecuencia al mantener el estado misógino y machista.

Para exponer esto era importante ese breve documental de la ciudad al principio del filme, donde nada funciona: no funcionan las vías públicas, no funcionan las políticas públicas, no funciona el gobierno, no funciona la familia, no funciona la policía, no funciona el Estado, en fin, no funciona ninguno de los engranes de la vida social. Le dicen 
al protagonista que es "un pinche error de la naturaleza", pero es claro que el policía no entiende el punto: le debió haber reconocido que él no es ningún error, sino el obvio resultado de un estado "natural" (es decir, fallido) de las cosas.

\section{CONCLUSIONES: UN FOUND FOOTAGE PARA MAÑANA}

El propósito de este texto fue presentar al found footage como una película que establece una posición de la cámara distinta a la ficción y la no ficción. Para ello, primero se discutió, brevemente, la ontología de la cámara, y lo beneficioso que puede ser para profundizar el análisis pasar de la distinción entre objeto de representación y representación del objeto a la distinción entre representación del objeto y enunciación de esa representación.

Estableciendo la diferencia entre ficción y no ficción, con el papel que juega la cámara en ambas, identificamos la cámara del found footage como no solo un objeto en la diégesis (lo que la sacaría del registro de la ficción), sino, además, una película que se presenta como carente de edición y armado (lo que la sacaría también del registro de la no ficción), por lo que entra en una dimensión de la espectacularización del archivo.

El análisis de algunos found footage de los últimos veinte años permite distinguir que estos ejes apuntan a una inestabilidad de la agencia autoral, tanto en el sentido de un autor incapaz (los personajes documentalistas que no tienen poder sobre la filmación) como de un autor que enuncia desde otra dimensión (que adquiere poder sobre la capacidad de enunciación de la cinta).

No pasa despercibido que todos los ejemplos examinados sean obras de terror o ciencia ficción. Las características de las historias de estos géneros remitirían a personajes que se enfrentan a tragedias, desgracias o lo desconocido, justificando su vulnerabilidad y falta de poder sobre el producto que están realizando. El found footage de terror ha sido trabajado específicamente por Hubber (2017), cuyas aproximaciones, si bien coinciden en algunos puntos con los cinco ejes clave que presenté, difieren en dos asuntos que considero fundamentales, y que no pueden entenderse sin incluir la brecha entre el enunciado y la enunciación.

El primero de ellos es que Hubber (2017) identifica el estilo del found footage como potencializador del concepto de trauma (en el sentido sociopolítico del término, no en el psicoanalítico, es decir, como un estado afectivo que retorna e insiste) a través de un sentido de "inmediación e inmersión" (p. 1). Este sentido "quizá" pueda adquirirse en algunos productos audiovisuales ${ }^{18}$, pero es difícil considerar que el espectador se siente más "inmediato e inmerso" en películas como Domingo, donde precisamente ese estilo de filmación imposibilita que el espectador adquiera un sentido de inmediatez e

18 La pornografía gonzo es el mejor ejemplo. Véase el trabajo de Maina y Zecca (2016). 
inmersión en el espacio, habitando en una brecha irreductible entre la representación y la enunciación de esa representación.

El segundo de los asuntos, y el que tiene implicaciones filosóficas más grandes, es que Hubber (2017) identifica el found footage como un género que nos convoca a buscar pistas en la pantalla "para investigar la evidencia visual del metraje en búsqueda de alguna verdad enterrada" (p. 15) ${ }^{19}$. El problema de seguir pensando en "la verdad oculta" es que perdemos de mira la dimensión de la verdad del decir (no que lo que se diga sea verdad, sino la verdad del propio acto de decir). Nuevamente, se pasa por alto que el documental dice la verdad en sus enunciados, pero a costa de ocultar su enunciación: se pierde de vista que hay una verdad en el decir mismo, más allá de lo que se diga.

El registro de la enunciación no es simplemente "el contexto" (como una pragmática de la comunicación humana podría apuntar). La enunciación opera incluso en aquellos lugares donde aparenta "solo" haber enunciado, aquellos lugares libres de la subjetividad del que enuncia, una vez que se decide que el contexto "es suficiente".

Aquí podríamos separar nuevamente el found footage de la no ficción. En el cine documental más tradicional, epitomizado por el documental científico o educativo, se presentan "solo" hechos puros, enunciados sin enunciación. Pero, más bien, debemos ver el documental como una película esforzada por esconder su enunciación: sus enunciados "objetivos" señalan su esfuerzo particular por esconder su enunciación.

Curiosamente, esto no es lo mismo que decir que el documental miente. El documental más tradicional expone mucho saber: ciertamente, sabe muchas cosas, pero lo hace ocultando la verdad de su enunciación. Es decir, aun cuando miente (cabe recordar que para Plantinga un documental que dice muchas mentiras no deja de ser documental), dice la verdad de su enunciación en la formulación de la mentira misma.

Una vez que dejamos de entender la distinción entre ficción y no ficción como una película "falsa" y una "verdadera", no debemos caer en la trampa posmoderna de que ficción y no ficción "se confunden", o que sus fronteras "se borran". Existe la ficción y la no ficción, pues la segunda apunta a una dimensión estructural de la verdad. Esto es innegable: la no ficción es una película que siempre habla sobre la verdad (que diga la verdad o no es otra discusión), y esta es la lección psicoanalítica sobre la verdad que siempre se dice a medias ${ }^{20}$.

Entonces, el found footage no queda solo como una estrategia que presenta una historia "no verdadera" con el disfraz de un documental (como una aproximación muy

19 "To probe the visual evidence of the footage in search of some buried truth" (Hubber, 2017, p. 15).

20 El lugar esencial para entrar de lleno en esta discusión es el famoso escrito de Lacan (2009), "La ciencia y la verdad". 
superficial del falso documental, podría decir). El found footage nos habla de la imposibilidad de sus realizadores para llevar a término una filmación y, en el proceso, alguien adquiere esa agencia autoral sobre su producto. Estas películas son una estrategia del cine para señalar la imposibilidad de decir la verdad: alcanzan a decir que no llegamos a decir toda la verdad.

En el mundo de las "posverdades", y de la búsqueda histérica por hallar la verdad, debemos optar por reconocer que siempre decimos la verdad singular de nuestra enunciación. Lejos de abogar a favor de la posverdad o la eterna relatividad de la verdad, se opta por señalar que es solo en la imposibilidad de decir toda la verdad que se accede a una dimensión estructural de la verdad. Mientras que el enunciado habita en la dimensión del semblante, la enunciación habita en la dimensión de la estructura.

En vez que buscar "la verdad oculta", busquemos siempre la estructura que da origen al semblante, la verdad de la enunciación que siemrpe está presente incluso entre "enunciados objetivos". Lo que hallamos en el found footage no es la "verdadera verdad", sino la única verdad capaz de decirse: es imposible decir toda la verdad.

\section{REFERENCIAS}

Aguilar, S. (2020). Del falso documental a lo falso de los documentales: el falso documental como síntoma del documental. adComunica. Revista Científica de Estrategias, Tendencias e Innovación en Comunicación, 19, 41-59.

Arnheim, R. (1958). Who is the author of a film? Film Culture, 16, 88-95.

Baron, J. (2014). The archive effect. Found footage and the audiovisual experience of history. Routledge.

Bettinelli-Olpin, M., Bruckner, D., Gillett, T., Martinez, J., McQuaid, G., Radio Silence, Swanberg, J., Villella, C., West, T., y Wingard, A. (directores). (2012). V/H/S [película]. 8383 Productions, Bloody Disgusting, Studio71, The Collective Studios.

Bordwell, D. (1985). Narration in the fiction film. University of Wisconsin Press.

Branigan, E. (2006). Projecting a camera. Language-games in film theory. Routledge.

Brice, P. (director). (2014). Creep [película]. Bloomhouse Productions, Duplass Brothers Productions.

Comanducci, C. (2018). Spectatorship and film theory. The wayward spectator. Palgrave Macmillan.

Godfrey, M. (2007). The artist as historian. October, 120, 140-172.

Hanich, L., y Holtzman, S. (productores). (2014). Cosmos [serie de televisión]. Cosmos Studios, Fuzzy Door Productions. 
Hubber, D. (2017). Exhuming the past: found-footage horror and national wounds. Frames. Cinema Journal, 11, 1-24.

Kuhn, A., y Westwell, G. (2012). Oxford dictionary of film studies. Oxford University Press.

Lacan, J. (2009). La ciencia y la verdad. En Escritos 2 (pp. 813-834). Siglo xxı Editores.

Leyda, J. (1964). Films beget films. Hill and Wang.

Maina, G., y Zecca, F. (2016). Harder than fiction: the stylistic model of gonzo pornography. Porn Studies, 3-4, 337-350.

Moran, J. (director). (2015). Always Watching: A Marble Hornets Story [película]. Bellevue Productions, Mosaic.

Myrick, D., y Sánchez, E. (directores). (1999). The Blair Witch Project [película]. Haxan Films.

Neos Nora (director). (director). (2016). Hikikovlogs [película]. Neos Nora; David Igneas (productores).

Nichols, B. (2010). Introduction to documentary. Indiana University Press.

Ortega, L. (director). (2015). Atroz [película]. Cinenauta, Grotesque, LSD Audio, Zebra Studios, rABYA Producciones.

Plantinga, C. R. (1996). Moving pictures and the rhetoric of nonfiction: two approaches. En N. Carroll y D. Bordwell (Eds.), Post-theory. Reconstructing film studies (pp. 307-324). University of Wisconsin Press.

Plantinga, C. R. (2010). Rhetoric and representation in nonfiction film. Chapbook Press.

Rojas, J. (2015). El documental, entre definiciones e indefiniciones. Aisthesis, 58, 279-312.

Spielberg, S. (director). (2005). War of the Worlds [película]. Paramount Pictures; DreamWorks; Amblin Entertainment.

Vigalondo, N. (director). (2006). Domingo [película]. Arsénico P. C.

Villegas, P. C. (2009). Aproximaciones al territorio de la no ficción. Revista KEPES, 6(5), 157-168.

Wees, W. C. (1993). Recycled images. The art and politics of found footage films. Anthology Film Archives. 